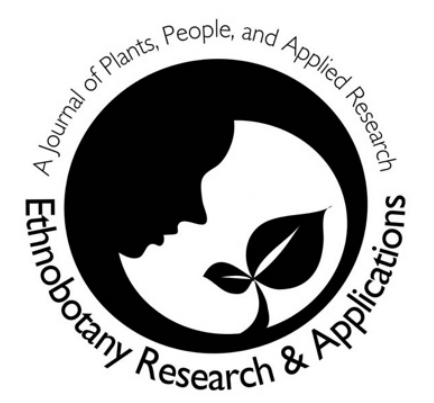

Quantitative

\title{
Ethnobotanical Study of
}

Poisonous Medicinal

Plants used in the

Traditional

\section{Pharmacopoeia of the Central Middle Atlas Region: Morocco}

Mariame Najem, Jamal Ibijbijen, Laila Nassiri

\section{Databases and Inventories}

\begin{abstract}
Background: This is the first quantitative study of poisonous medicinal plants in which the practitioners of traditional medicine in the Moroccan central Middle Atlas region were interviewed to document and analyze their traditional ethnobotanical knowledge used to prepare plant-based drugs.
\end{abstract}

Methods: To collect ethnobotanical data on poisonous medicinal plants, 58 practitioners of traditional medicine were interviewed. The quantitative measurement of the obtained data was accomplished by quantitative indices such as the use value (UV), family use value (FUV), relative frequency of citation (RFC), fidelity level (FL), relative importance $(\mathrm{RI})$, informant consensus factor (ICF), and cultural importance index (Cl).

Results: Among the 83 poisonous medicinal plants recorded, Ruta montana L. had the highest rate of UV (2.293). Furthermore, Anacyclus pyrethrum L. demonstrated the highest RFC (0.810), while Carum carvi $\mathrm{L}$. had both the highest $\mathrm{RI}(95)$ and $\mathrm{Cl}(0.155)$. Five species were distinguished for their high-fidelity levels, among which Aristolochia paucinervis Pomel had the highest $\mathrm{FL}$ values for the treatment of dermatological and digestive disorders. The other four species were Ruta montana L. for treating respiratory, oral, and neurological diseases, Urtica urens L. for treating osteoarticular and urogenital diseases, Verbascum sinuatum L. for treating ophthalmic diseases, and Ammi visnaga, (L.) Lam. for treating cardiovascular disorders. Ophthalmic disorders had the highest value of ICF (0.743), and a very significant positive correlation was observed between RFC and UV $\left(R^{2}=0.5968\right)$ and between $R I$ and $\mathrm{Cl}\left(\mathrm{R}^{2}=0.9999\right)$ was observed.

Conclusions: The present study reveals that traditional medicine practitioners in the central Middle Atlas region utilize many poisonous medicinal plants in traditional herbal medicine. Although these plants have therapeutic virtues, their toxic potency necessitates vigilance in use.

Key words: Poisonous medicinal plants, Quantitative ethnobotany, Taditional phytotherapy, Central Middle Atlas region

Correspondence
Mariame Najem*, Jamal Ibijbijen, Laila Nassiri
Environment \& Soil Microbiology Unit, Moulay Ismail
University, Faculty of Sciences, B.P:11201 Meknes,
Morocco
*Corresponding author: mariamenajem@gmail.com
Ethnobotany Research \& Applications
18:36 (2019)




\section{Résumé}

Contexte: Le présent travail constitue la première étude quantitative portant sur les plantes toxiques sollicitées par les acteurs de la médecine traditionnelle au Moyen Atlas central marocain ; il a pour but principal d'analyser le savoir culturel et botanique traditionnel utilisé dans la préparation de médicaments à base de plantes.

Méthodes: Pour collecter les données ethnobotaniques concernant les plantes toxiques utilisées en phytothérapie traditionnelle, 58 acteurs de la médecine ancestrale ont été interrogés. L'expression quantitative des données obtenues est réalisée via le calcul de différents indices quantitatifs, tels que :la valeur d'usage (UV), la valeur d'usage des familles (FUV), la fréquence de citation relative (RFC), l'indice de fidélité ( $F L)$, le facteur de consensus des informateurs (ICF), l'importance relative $(\mathrm{RI})$ et l'indice de l'importance culturelle $(\mathrm{CI})$.

Résultats: Sur les 83 plantes toxiques inventoriées, Ruta montana L. présente la valeur d'usage la plus élevée (UV=2,293), Anacyclus pyrethrum L. a la fréquence de citation la plus importante (RFC=0,810), Carum carvi L. possède à la fois, l'importance relative $(\mathrm{RI})$ et l'importance culturelle (CI) les plus élevées $(\mathrm{RI}=95, \mathrm{Cl}=0,155)$. L'indice de fidélité est le plus élevé pour 5 espèces, Aristolochia paucinervis Pomel. est la plus utilisée pour le traitement des affections dermatologiques et digestives, Ruta montana L. pour les affections respiratoires, orales et neurologiques, Urtica urens L. pour celles ostéoarticulaires et urogénitales, Verbascum sinuatum L. pour le traitement des maladies ophtalmiques et Ammi visnaga (L.) Lam. pour les affections cardiovasculaires. À signaler que les affections ophtalmiques détiennent la valeur la plus élevée du facteur de consensus des informateurs $(F I C=0,743)$. Aussi, une corrélation positive très significative entre RFC et UV $\left(R^{2}=0,5968\right)$ et entre $\mathrm{Rl}$ et $\mathrm{Cl}\left(R^{2}=0,9999\right)$ est observée.

Conclusions: Cette étude révèle que les acteurs de la médecine traditionnelle au Moyen Atlas central ont recours à l'utilisation d'un nombre important de plantes toxiques en phytothérapie traditionnelle ; certes, ces plantes ont des vertus thérapeutiques mais leur potentiel toxique impose une grande vigilance.

Mots clés: Plantes médicinales toxiques, Ethnobotanique quantitative, Phytothérapie traditionnelle, Région du Moyen Atlas central.

\section{Background}

Morocco, with its distinguished plant richness resulting from the heterogeneity of its habitats, landscapes, climate, and geological events, occupies a remarkable place in the biodiversity of the Mediterranean region (Jamaleddine et al. 2017). According to a previous report (Fennane \& Ibn Tattou 2012), Moroccan vascular flora comprises 3913 species and 1298 subspecies (including 426 typical subspecies) distributed among 155 families and 981 genera shaped by the empirical knowledge of the Moroccan population over historical time, verbal transmission through generations, and the mixture of Amazigh and Arab-Muslim civilizations where the floral wealth and especially the medicinal potential of plants have been highly valued (Bellakhdar 1997, El Rhaffari \& Zaid 2002). This heritage stimulated the curiosity of many Moroccan and Arab researchers, including Ibn Al Baytar (1248), Dâûd al-Antaki (1592), Bellakhdar (1997), and Merzouki (1997) (El Rhaffari \& Zaid 2002). Currently, plant medication is becoming increasingly important through scientific studies based on analytical methods and new experiments that test the efficacy of empirical herbal recipes.

Ethnobotany is considered a science that enables to translate traditional wisdom into scientific knowledge based on field work consisting of the understanding of the traditional health system and identifying plant origin substances for therapeutic purposes (Fleurentin 1993). Studies in ethnobotany can be descriptive by focusing on defining a set of plants used by a given community to determine the factors that might explain the use and knowledge of plants or by testing the effectiveness and validity of certain techniques and methods in case of diagnostic ethnobotanical study (De Albuquerque \& Hanazaki 2009). Since the 1990s, several data collection techniques have been proposed, and many authors adopted them in their ethnobotanical research; however, the use of these analytical methods can be challenging, and researchers must be aware that "measuring" traditional knowledge involves theoretical and practical dimensions (Houéhanou et al. 2016). It is worth mentioning that quantitative studies can be used to test hypotheses and/or knowledge regarding natural resources by referring to the indices that were calculated, which generally incorporate in their calculations other indices that are primary quantitative parameters or basic indices. These comprise the frequency of citation, the relative frequency of citation, the number of uses of the species, and the number of reported uses of the species (Houéhanou et al. 2016). Therefore, to complete partial and fragmentary studies conducted throughout Morocco, the objective of the present 
investigation was to carry out a quantitative study of ethnobotanical data from a survey of medicinal plants recommended by traditional medicine practitioners in the Moroccan central Middle Atlas region.

\section{Materials and methods}

\section{The study area}

The Middle Atlas is a mountain range that extends over $450 \mathrm{~km}$ and covers a total area of $27550 \mathrm{~km}^{2}$ (El Jihad 2016). It constitutes the water tower of Morocco, with four watersheds of the largest Moroccan rivers:Sebou, Moulouya, Oum Rabia, and Bou Regreg.

\section{Climate}

The study area has a Mediterranean-type climate. The altitudinal position, geographical situation, and exposure to oceanic influences cause semi-arid, sub-humid, and humid bioclimates, and their thermal variants range from cool through cold to even very cold (Martin 1981).

\section{Soil}

Starting from marl clay formations resting on a continuous slab of lacustrine limestone at the Meknes plain, the Middle Atlas regions evolve into red or brown forest soils formed mainly on limestone or dolomite, regardless of the altitude or exposure, in semi-arid, humid, or sub-humid bioclimates (Mahmoudi \& Bertrand 2007).

\section{Ecosystems and study sites}

In the central Middle Atlas region, the flora and fauna are very rich; they contain many endemic, rare, and very remarkable species (Benabid 2002). The vegetation is very diverse and the phytocenoses are luxuriant due to precipitation in the form of rain or snow according to the altitude (Benbrahim et al. 2004) and have the most important forest potential of Morocco. All types of Moroccan natural ecosystems are represented except those of the arid and Saharan zones (Benabid 2002). This forest potential is a strategic issue for the region as it constitutes a protective and productive heritage, a genetic reservoir of biodiversity, and is therefore an important socio-economic space in addition to being recreational and cultural (Boujrouf 2004).

We conducted our fieldwork in El Hajeb in Elhajeb province, Azrou, Ifrane, and Timahdite in Ifrane province, and Khenifra and M'rirt in Khenifra province (Fig. 1).

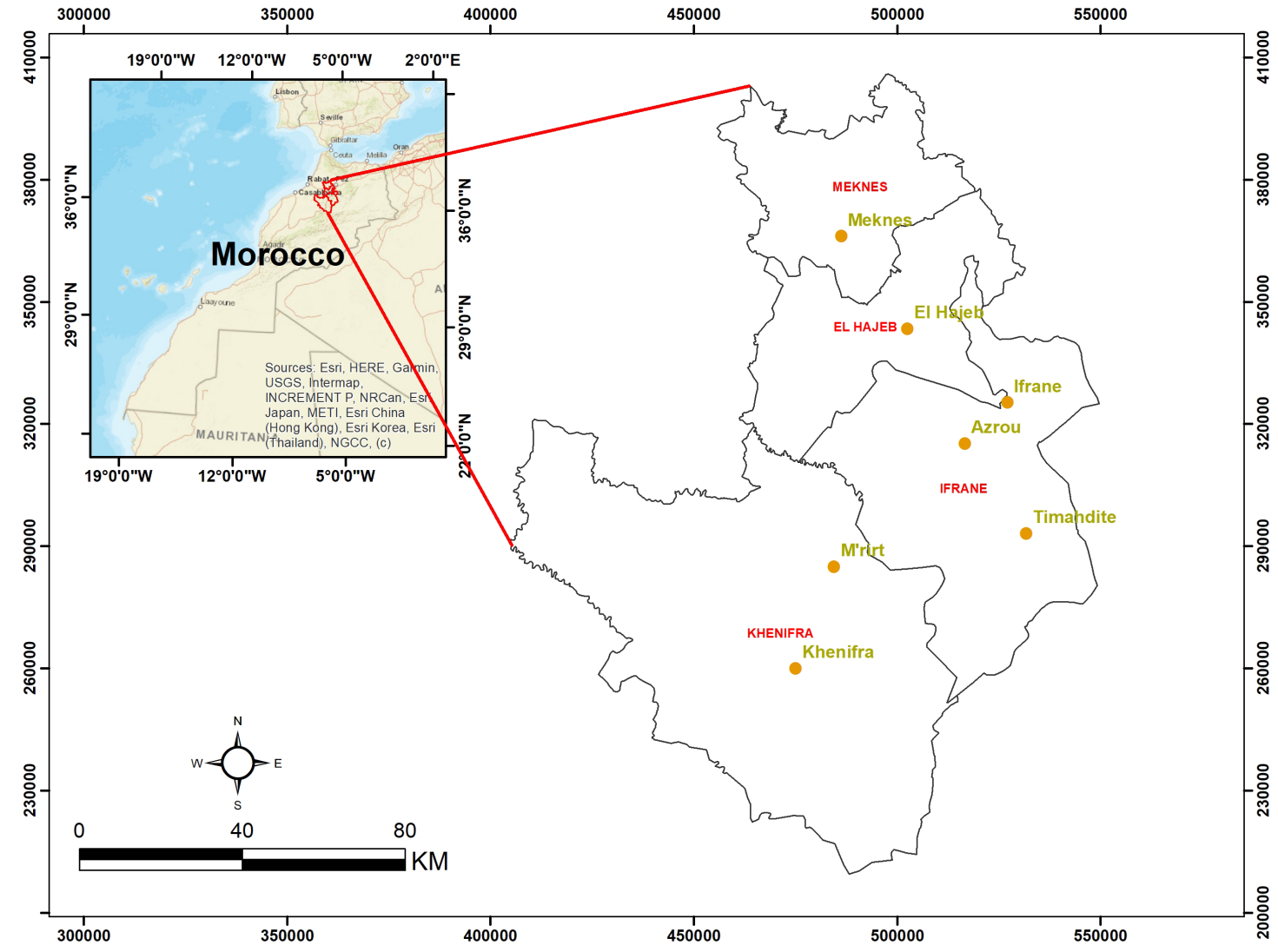

Fig.1. Study area (Red indicates provinces and green indicates cities or villages). 
The characteristics of the informants

To determine the sample size $(\mathrm{N})$, we compiled a list of traditional medicine practitioners in the study area, which enabled us to determine the parent population (P) consisting of 290 different categories:60 traditional healers, 105 herbalists, and 125 pharmacists. To obtain a representative sample, the ratio between the desired sample and the parent population (N/P) must be between $15 \%$ and $20 \%$ (Nacoulma et al. 2006). In our case (N/P = 20\%), N was equal to 58 , including 12 traditional healers, 21 herbalists, and 25 druggists who were all from the study area and represent the 58 practitioners of traditional medicine chosen based on their reputations in the field. In their opinion, herbal medicine is a heritage based on ancestral knowledge transferred from one generation to the next and the plants represent an integral part of their daily lives. Most of the respondents were men aged 18 to 70 years.

\section{Data collection and interview methods}

We used the free listing technique commonly used in social and behavioral sciences, ethnozoology, and ethnobotany (Miranda et al. 2007). The 58 respondents were asked to list the medicinal plants they knew, and the interviews were conducted over a seven-month period. The interviews were conducted in Arabic. The surveys were rarely completed in a single outing because the informants would not provide all the information in one session. We sometimes had to return several times to the informant and show patience and availability to collect the information that was directly relevant to our ethnobotanical survey.

\section{The choice of criteria}

Inclusion criteria: Only plants that are spontaneous or cultivated in the study area and are used by the respondents were selected.

Exclusion criteria: Any plants not used by the respondents or that do not grow in the study area were excluded.

\section{Systematic determination}

Each listed poisonous medicinal plant was sampled and numbered for taxonomic determination in the laboratory according to Morocco's practical flora (Fennane et al.1999, Fennane et al. 2007, Fennane et al. 2014)

\section{Data analysis}

\section{Statistical analysis}

The recorded data were tabulated using spreadsheets (Excel) and analyzed statistically using SPSS Statistics 20 software. We calculated the standard descriptive statistics and correlation analyses based on simple linear regression.
Quantitative analyses of the ethnobotanical data The collected data were used to calculate various quantitative indices, including the use value (UV), family use values (FUV), relative frequency of citation (RFC), fidelity level (FL), informant consensus factor (ICF), relative importance (RI), and cultural importance index (Cl) (Pardo-de-Santayana et al. 2007, Cadena-González et al. 2013, Nawash et al. 2013, Vitalini et al. 2013, Yassen et al. 2015).

\section{Use value (UV)}

The use value (UV) was used to demonstrate the relative importance of plants known locally. It was calculated using the following formula (Vitalini et al. 2013):

$$
\mathbf{U V}=\sum_{\mathbf{i}=\mathbf{1}}^{\mathbf{i}=\mathbf{N}} \mathbf{U i} / \mathbf{N}
$$

where $\mathrm{Ui}=$ the number of uses mentioned by an informant $\mathrm{i}$ and $\mathrm{N}=$ the total number of informants interviewed.

\section{Family use values (FUV)}

The family use values (FUV) were used to identify the significance of plant families. It was calculated using the following formula (Cadena-González et al. 2013):

$$
F U V=U V_{s} / N_{s}
$$

where $U V_{s}=$ the use value of species belonging to the same family and $\mathrm{N}_{\mathrm{s}}=$ the total number of species present in a given family.

\section{Relative frequency of citation (RFC)}

The relative frequency of citation (RFC) was used to demonstrate the local importance of each species. It was calculated using the following formula (Vitalini et al. 2013):

$$
\mathrm{RFC}=\mathrm{FC} / \mathrm{N}
$$

where $\mathrm{FC}=$ the number of informants mentioning the use of the species and $\mathrm{N}=$ the total number of informants interviewed.

\section{Fidelity level (FL)}

The fidelity level (FL) was used to determine the most ideal species used to treat a specific ailment (Musa et al. 2011). It was calculated using the following formula (Nawash et al. 2013):

$$
F L(\%)=\left(N_{p} / N\right) \times 100
$$

where $N_{p}=$ the number of the informants who reported using a given species to treat an illness and $\mathrm{N}=$ the total number of informants interviewed.

Informant consensus factor (ICF) 
The informant consensus factor was used to measure the agreement between informants about the use of plants for specific use categories. It was calculated using the following formula (Heinrich et al. 1998):

$$
I C F=\left(N_{u r}-N_{t}\right) /\left(N_{u r}-1\right)
$$

where $\mathrm{N}_{\mathrm{ur}}=$ the number of use reports for a particular ailment category and $N_{t}=$ the number of plants mentioned for the treatment of this particular ailment category.

The ICF ranged from zero to one. A value close to one indicates a high intracultural consensus (most of the informants used the same species to treat the same illnesses) and a value close to zero indicates a high variation in the use of species (the informants disagreed over which species was used for treatment within a category of illness) (Heinrich M., Ankli A. et al. 1998).

\section{Relative importance (RI)}

The relative importance (RI) was used to measure the versatile use and true value of plants (Bennett \& Prance 2000). It was calculated using the following formula (Yaseen et al. 2015):

$$
R I=(P P+A C) * 100 / 2
$$

where PP represents the pharmacological properties, which indicate the relative use reports that were calculated by dividing the number of use reports (UR) attributed to a species by the maximum number of use reports attributed to the most important species (the species with the highest number of use reports), and $A C$ represents the ailments treated, which indicates the relative body systems treated. AC was calculated by dividing the number of body systems treated by a given species by the maximum number of ailment categories treated by the species that were used most widely.

\section{Cultural importance index $(\mathrm{Cl})$}

The cultural importance index $(\mathrm{Cl})$ was used to assess the importance of each species (Singh et al. 2019). It was calculated using the following formula (Pardo-de-Santayana et al. 2007)

$$
\mathrm{Cl}=\sum_{\mathbf{i}=1}^{\mathbf{i}=\mathrm{NU}} \mathrm{URi} / \mathbf{N}
$$

Where UR $\mathrm{i}=$ the number of use reports of species for different use categories (i, varying from only one use to the total number of uses) and $\mathrm{N}=$ the total number of informants interviewed.

\section{Results and discussion}

The results demonstrate that among the 125 medicinal plants listed, 83 were reported to be poisonous and were distributed over 36 families and 74 genera.

Use value (UV)

The UV of the toxic plants recommended in the study area ranged from 2.293 to 0.017 (Table 1). The toxic species showing a strong potential for ethnobotanical use are Ruta montana L. (2.293), Urtica urens (1.914), Ammi visnaga (L.) Lam (1.328), Aristolochia paucinervis Pomel (1.241), Verbascum sinuatum L. (1.207), Marrubium vulgare L. (1.155), Anacyclus pyrethrum L. (0.759), Chenopodium ambrosioides L. (0.879), Laurus nobilis L. (0.621), Corrigiola telephiifolia Pour. (0.603), and Solanum sodomaeum L. (0.569).

The high UV reflects the importance attributed to a species by the respondents as a result of its therapeutic virtues and not necessarily its availability in the study area; however, it may also express the harvesting pressure that could be exerted on the species (Dossou et al. 2012). It also does not specify whether a plant has multiple or unique uses (Zougagh et al. 2019). The intensive use of certain species presents a real health risk because they are highly recommended by the traditional medicine practitioners in the central Middle Atlas region despite their toxicity (Najem et al. 2018a). Among these, Aristolochia paucinervis (Pomel.) was mentioned, which is very toxic, related to the presence of aristolochic acid with carcinogenic and nephrotoxic potency. It alters the liver and kidney enzymes (Bnouham et al. 2006, Rankou et al. 2015). In 2005, the Oncology Department of the University Hospital of Casablanca in Morocco reported two deaths and 5 cases of aplastic anemia due to the use of Aristolochia paucinervis Pomel. In 2010, according to statistics from the Moroccan Poison Center, $16 \%$ of kidney failure cases were recorded in patients with malignant tumors who used the plant during traditional cancer treatment (Benzakour et al. 2011). Similarly, the furanocoumarins of Ruta montana L. are toxic to the kidney and liver, and even carcinogenic, because they alter the nucleic acids and can thus cause lesions of the genome (Seak \& Lin 2007). These furanocoumarins are phototoxic induced by contact with the leaves, followed by exposure to the sun, causing acute dermatitis that resembles a first- or second-degree burn; secondarily, the skin will undergo hyperpigmentation that can persist (Masri et al. 2015). R. montana is not used in Europe but is still solicited by traditional healers, especially in the Mediterranean and South America (Masri et al. 2015) 
Ethnobotany Research and Applications

Table 1. List of toxic plants used in the traditional pharmacopoeia of the central Middle Atlas

\begin{tabular}{|c|c|c|c|c|c|c|c|c|c|c|c|}
\hline Family / scientific names & $\begin{array}{l}\text { Local } \\
\text { names }\end{array}$ & $\begin{array}{l}\text { Herbarium } \\
\text { specimen } \\
\text { number }\end{array}$ & Ui & UV & Fc & RFc & UR & $\mathbf{C l}$ & PP & AC & $\mathbf{R I}$ \\
\hline \multicolumn{12}{|l|}{ Acanthaceae } \\
\hline Acanthus mollis L. & Sebana & $2682 / I S / N^{\circ} 38$ & 13 & 0.224 & 9 & 0.155 & 2 & 0.034 & 0.22 & 0.2 & 21.11 \\
\hline \multicolumn{12}{|l|}{ Amaranthaceae } \\
\hline Chenopodium ambrosioides L. & Mkhinza & $247 / I S / N^{\circ} 36$ & 51 & 0.879 & 24 & 0.414 & 2 & 0.034 & 0.22 & 0.2 & 21.11 \\
\hline \multicolumn{12}{|l|}{ Anacardiaceae } \\
\hline Pistacia atlantica Dsf. & Lebtem & $1810 / \mathrm{IS} / \mathrm{N}^{\circ} 38$ & 30 & 0.517 & 22 & 0.379 & 3 & 0.052 & 0.33 & 0.3 & 31.67 \\
\hline Pistacia lentiscus L. & Drou & $1809 / I S / N^{\circ} 38$ & 23 & 0.397 & 14 & 0.241 & 1 & 0.017 & 0.11 & 0.1 & 10.56 \\
\hline \multicolumn{12}{|l|}{ Apiaceae } \\
\hline Ammi majus L. & Aatrilal & $2025 / I S / N^{\circ} 38$ & 12 & 0.207 & 11 & 0.190 & 1 & 0.017 & 0.11 & 0.1 & 10.56 \\
\hline Ammi visnaga (L.) Lam & $\begin{array}{c}\text { Bachnikha/ } \\
\text { khala }\end{array}$ & $2024 / I S / N^{\circ} 38$ & 77 & 1.328 & 21 & 0.362 & 3 & 0.052 & 0.33 & 0.3 & 31.67 \\
\hline Anethum graveolens L. & Chibt & $2041 / I S / N^{\circ} 38$ & 1 & 0.017 & 1 & 0.017 & 2 & 0.034 & 0.22 & 0.2 & 21.11 \\
\hline Angelica archangelica L. & $\begin{array}{l}\text { hachichat } \\
\text { malaeka }\end{array}$ & 23/PTM & 5 & 0.086 & 5 & 0.086 & 6 & 0.103 & 0.67 & 0.6 & 63.33 \\
\hline Carum carvi L. & Kerwiya & 30/PTM & 22 & 0.379 & 17 & 0.293 & 9 & 0.155 & 1.00 & 0.9 & 95.00 \\
\hline Coriandrum sativum L. & Kesbour & $1955 / I S / N^{\circ} 38$ & 7 & 0.121 & 3 & 0.052 & 1 & 0.017 & 0.11 & 0.1 & 10.56 \\
\hline Ferula communis L. & $\begin{array}{l}\text { Boubal, } \\
\text { Ikellikha }\end{array}$ & $2044 / I S / N^{\circ} 38$ & 15 & 0.259 & 9 & 0.155 & 3 & 0.052 & 0.33 & 0.3 & 31.67 \\
\hline Foeniculum vulgare P. Mill. & Besbas & $1991 / \mathrm{IS} / \mathrm{N}^{\circ} 38$ & 18 & 0.310 & 5 & 0.086 & 3 & 0.052 & 0.33 & 0.3 & 31.67 \\
\hline Pimpinella anisum L. & Habat hlawa & 46/PTM & 27 & 0.466 & 9 & 0.155 & 4 & 0.069 & 0.44 & 0.4 & 42.22 \\
\hline \multicolumn{12}{|l|}{ Apocynaceae } \\
\hline Nerium Oleander L. & Defla & $2079 / I S / N^{\circ} 38$ & 17 & 0.293 & 14 & 0.241 & 3 & 0.052 & 0.33 & 0.3 & 31.67 \\
\hline \multicolumn{12}{|l|}{ Aristolochiaceae } \\
\hline Aristolochia paucinervis Pomel & Bereztam & $81 / I S / N^{\circ} 36$ & 72 & 1.241 & 32 & 0.552 & 3 & 0.052 & 0.33 & 0.3 & 31.67 \\
\hline \multicolumn{12}{|l|}{ Asteraceae } \\
\hline Achillea millefolium L. & Kala & 61/PTM & 9 & 0.155 & 6 & 0.103 & 2 & 0.034 & 0.22 & 0.2 & 21.11 \\
\hline Atractylis cancellata L. & Nejma & $2870 / I S / N^{\circ} 40$ & 4 & 0.069 & 4 & 0.069 & 3 & 0.052 & 0.33 & 0.3 & 31.67 \\
\hline
\end{tabular}

Published: 08 November 2019

http://dx.doi.org/10.32859/era.18.36.1-17 
Ethnobotany Research and Applications

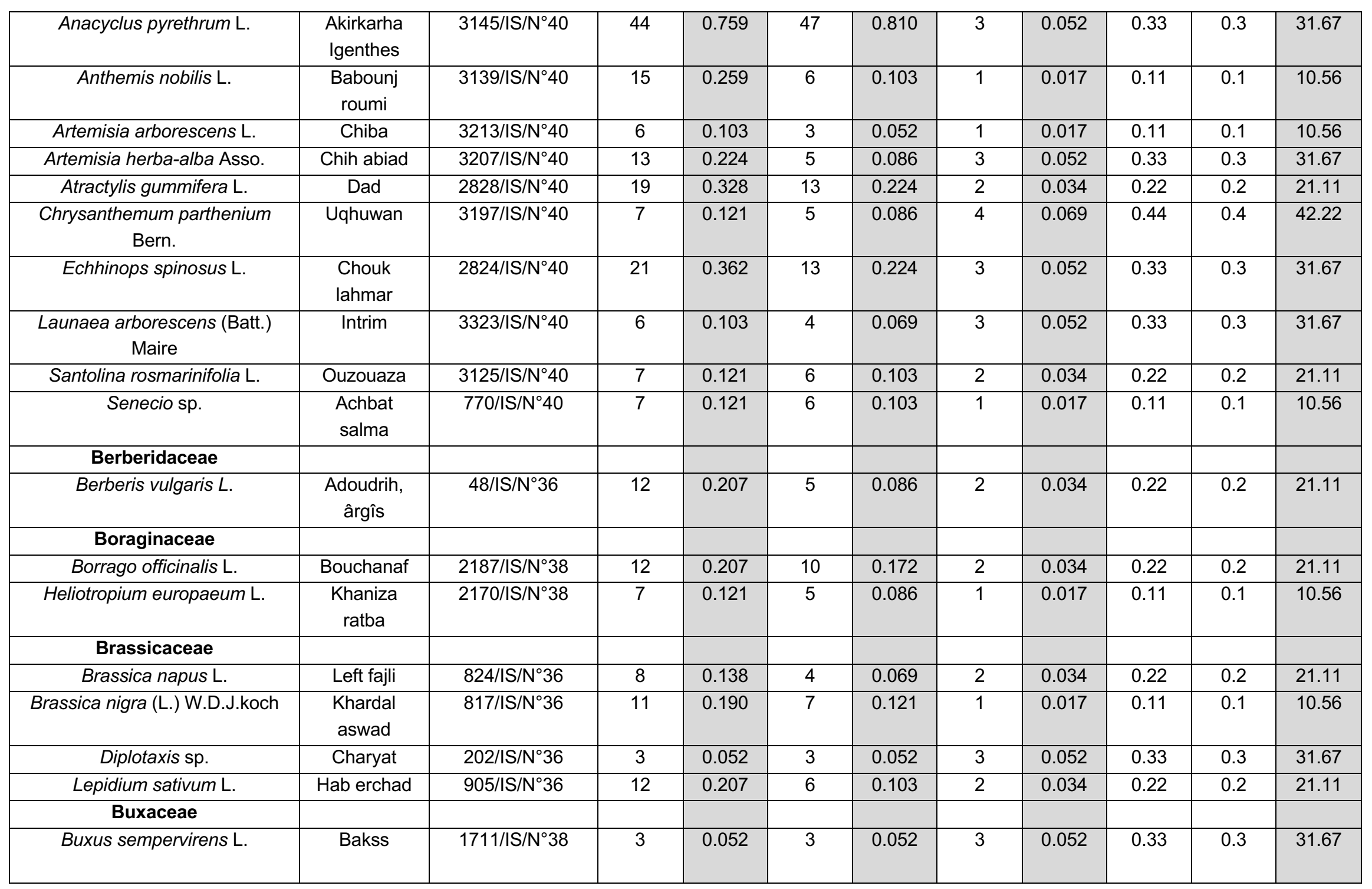

Published: 08 November 2019

http://dx.doi.org/10.32859/era.18.36.1-17 
Ethnobotany Research and Applications

\begin{tabular}{|c|c|c|c|c|c|c|c|c|c|c|c|}
\hline Caprifoliaceae & & & & & & & & & & & \\
\hline Sambucus nigra L. & Sembouqa & $2746 / \mathrm{IS} \mathrm{N}^{\circ} 40$ & 7 & 0.121 & 4 & 0.069 & 3 & 0.052 & 0.33 & 0.3 & 31.67 \\
\hline \multicolumn{12}{|l|}{ Caryophyllaceae } \\
\hline Corrigiola telephiifolia Pour. & serghina & $348 / I S / N^{\circ} 36$ & 35 & 0.603 & 30 & 0.517 & 4 & 0.069 & 0.44 & 0.4 & 42.22 \\
\hline Saponaria vaccaria L. & Hamrat erras & $559 / \mathrm{IS} / \mathrm{N}^{\circ} 38$ & 6 & 0.103 & 4 & 0.069 & 2 & 0.034 & 0.22 & 0.2 & 21.11 \\
\hline \multicolumn{12}{|l|}{ Cistaceae } \\
\hline Cistus ladaniferus L. & Touzal & $704 / \mathrm{IS} / \mathrm{N}^{\circ} 36$ & 9 & 0.155 & 9 & 0.155 & 1 & 0.017 & 0.11 & 0.1 & 10.56 \\
\hline \multicolumn{12}{|l|}{ Cyperaceae } \\
\hline Cyperus longus L. & Arouk esaad & $3702 / I S / N^{\circ} 40$ & 10 & 0.172 & 8 & 0.138 & 3 & 0.052 & 0.33 & 0.3 & 31.67 \\
\hline \multicolumn{12}{|l|}{ Ericaceae } \\
\hline Arbutus unedo L. & $\begin{array}{l}\text { Bakhanou } \\
\text { Sasnou }\end{array}$ & $1062 / I S / N^{\circ} 36$ & 5 & 0.086 & 2 & 0.034 & 1 & 0.017 & 0.11 & 0.1 & 10.56 \\
\hline \multicolumn{12}{|l|}{ Euphorbiaceae } \\
\hline Euphorbia helioscopia L. & Halib assou & $1744 / \mathrm{IS} / \mathrm{N}^{\circ} 38$ & 9 & 0.155 & 7 & 0.121 & 1 & 0.017 & 0.11 & 0.1 & 10.56 \\
\hline Euphorbia resinifera Berg. & $\begin{array}{l}\text { Louban } \\
\text { maghribi }\end{array}$ & $1727 / I S / N^{\circ} 38$ & 8 & 0.138 & 4 & 0.069 & 3 & 0.052 & 0.33 & 0.3 & 31.67 \\
\hline \multicolumn{12}{|l|}{ Fabaceae } \\
\hline Astragalus gummifera Labill. & Ktira & 229/PTM & 7 & 0.121 & 4 & 0.069 & 2 & 0.034 & 0.22 & 0.2 & 21.11 \\
\hline Astragalus lusitanicus Lam. & Fouila & $1315 / \mathrm{IS} / \mathrm{N}^{\circ} 38$ & 9 & 0.155 & 9 & 0.155 & 3 & 0.052 & 0.33 & 0.3 & 31.67 \\
\hline Trigonella foenum graecum L. & Halba & $1553 / I S / N^{\circ} 38$ & 18 & 0.310 & 7 & 0.121 & 3 & 0.052 & 0.33 & 0.3 & 31.67 \\
\hline \multicolumn{12}{|l|}{ Lamiaceae } \\
\hline Ajuga iva (L.) Schreb. & Chandgoura & $2250 / I S / N^{\circ} 38$ & 16 & 0.276 & 11 & 0.190 & 4 & 0.069 & 0.44 & 0.4 & 42.22 \\
\hline Calamintha officinalis Moench. & Manta & 301/PTM & 11 & 0.190 & 7 & 0.121 & 4 & 0.069 & 0.44 & 0.4 & 42.22 \\
\hline Hyssopus officinalis L. & $\begin{array}{l}\text { Azoufa } \\
\text { yabsa }\end{array}$ & $2449 / \mathrm{IS} / \mathrm{N}^{\circ} 38$ & 13 & 0.224 & 6 & 0.103 & 5 & 0.086 & 0.56 & 0.5 & 52.78 \\
\hline $\begin{array}{c}\text { Lavandula pedunculata (Miller) } \\
\text { Cav. subsp. atlantica (Br.-Bl.) } \\
\text { Romo }\end{array}$ & Khzama & $2317 / / \mathrm{S} / \mathrm{N}^{\circ} 38$ & 18 & 0.310 & 11 & 0.190 & 2 & 0.034 & 0.22 & 0.2 & 21.11 \\
\hline Marrubium vulgare L. & Mariouta & $2313 / \mathrm{IS} / \mathrm{N}^{\circ} 38$ & 67 & 1.155 & 21 & 0.362 & 3 & 0.052 & 0.33 & 0.3 & 31.67 \\
\hline Mentha pulegium L. & Fliyou & $2453 / I S / N^{\circ} 38$ & 11 & 0.190 & 7 & 0.121 & 4 & 0.069 & 0.44 & 0.4 & 42.22 \\
\hline Ocimum basilicum L. & Lahbak & 291/PTM & 14 & 0.241 & 11 & 0.190 & 3 & 0.052 & 0.33 & 0.3 & 31.67 \\
\hline
\end{tabular}


Ethnobotany Research and Applications

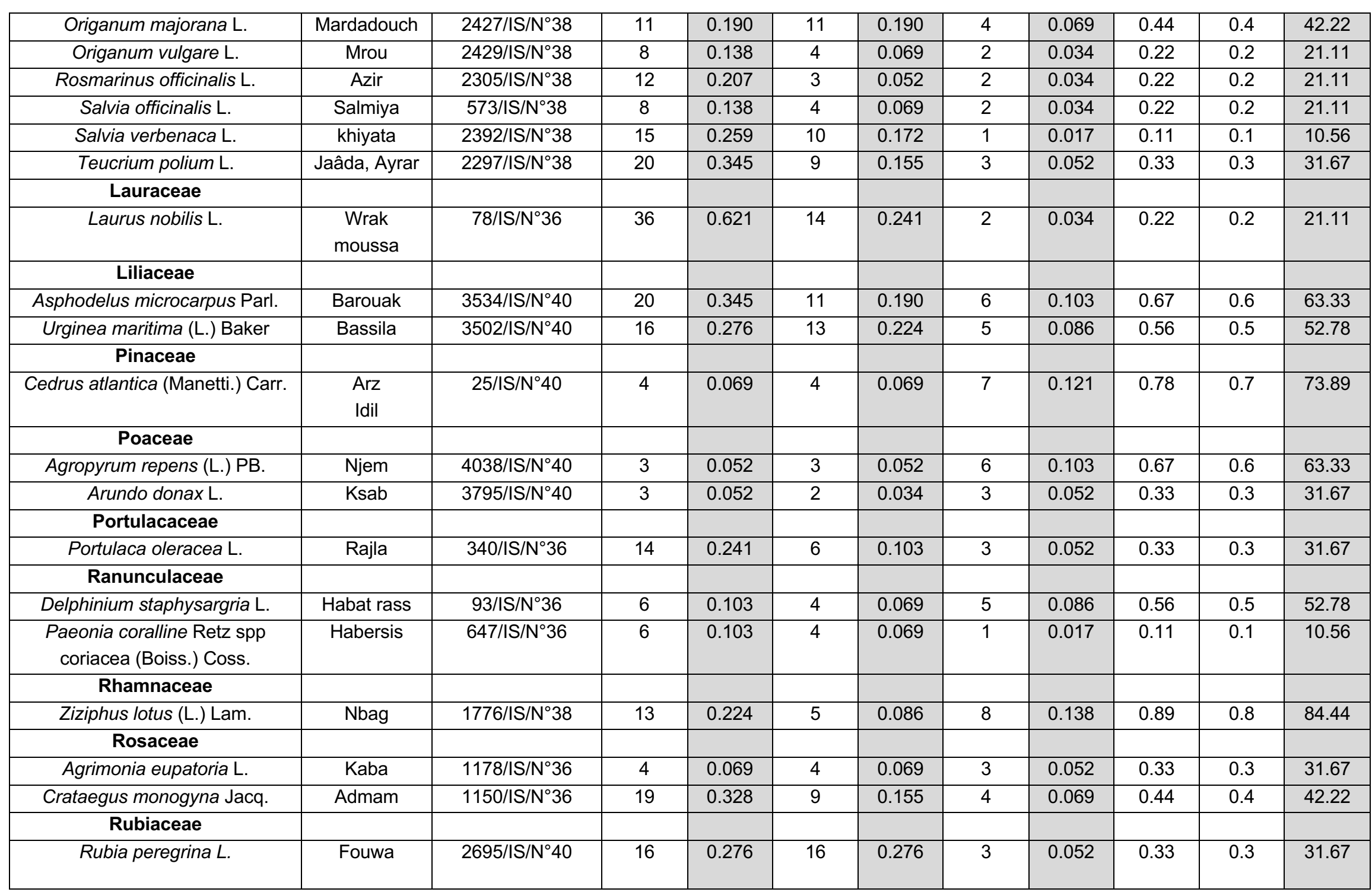

Published: 08 November 2019

http://dx.doi.org/10.32859/era.18.36.1-17 
Ethnobotany Research and Applications

\begin{tabular}{|c|c|c|c|c|c|c|c|c|c|c|c|}
\hline \multicolumn{12}{|l|}{ Rutaceae } \\
\hline Ruta montana L. & $\begin{array}{l}\text { Figel } \\
\text { Iwrni }\end{array}$ & $1815 / I S / N^{\circ} 38$ & 133 & 2.293 & 25 & 0.431 & 2 & 0.034 & 0.22 & 0.2 & 21.11 \\
\hline \multicolumn{12}{|l|}{ Scrophulariaceae } \\
\hline $\begin{array}{c}\text { Digitalis mauritanica (Emberger } \\
\text { \& Maire) Ivaina L. }\end{array}$ & Adabi & $2605 / I S / N^{\circ} 38$ & 8 & 0.138 & 8 & 0.138 & 2 & 0.034 & 0.22 & 0.2 & 21.11 \\
\hline Verbascum sinuatum L. & Maslah ndar & $2504 / I S / N^{\circ} 38$ & 70 & 1.207 & 29 & 0.500 & 2 & 0.034 & 0.22 & 0.2 & 21.11 \\
\hline \multicolumn{12}{|l|}{ Solanaceae } \\
\hline Hyoscyamus sp & Sikran & $509 / I S / N^{\circ} 38$ & 17 & 0.293 & 9 & 0.155 & 2 & 0.034 & 0.22 & 0.2 & 21.11 \\
\hline Solanum sodomaeum L. & Hadja & $2107 / / S / N^{\circ} 38$ & 33 & 0.569 & 20 & 0.345 & 3 & 0.052 & 0.33 & 0.3 & 31.67 \\
\hline \multicolumn{12}{|l|}{ Taxaceae } \\
\hline Taxus baccata L. & Dahs, îgen & $72 / I S / N^{\circ} 36$ & 10 & 0.172 & 7 & 0.121 & 4 & 0.069 & 0.44 & 0.4 & 42.22 \\
\hline \multicolumn{12}{|l|}{ Thymelaeaceae } \\
\hline Daphne gnidium L. & Alezzâz & $1667 / I S / N^{\circ} 38$ & 7 & 0.121 & 7 & 0.121 & 6 & 0.103 & 0.67 & 0.6 & 63.33 \\
\hline \multicolumn{12}{|l|}{ Urticaceae } \\
\hline Urtica urens & Hariga & $209 / I S / N^{\circ} 36$ & 111 & 1.914 & 31 & 0.534 & 3 & 0.052 & 0.33 & 0.3 & 31.67 \\
\hline \multicolumn{12}{|l|}{ Zygophyllaceae } \\
\hline Peganum harmala L. & Lharmel & $422 / I S / N^{\circ} 38$ & 11 & 0.190 & 4 & 0.069 & 1 & 0.017 & 0.11 & 0.1 & 10.56 \\
\hline
\end{tabular}


Solanum sodomaeum L. is known for its toxic potency due to its glycoalkaloid content, whose main aglycone is solasodine (Cham \& Meares 1987). Ingestion of one to two fruits induces gastrointestinal disorders accompanied by vertigo, confusion, and even hallucinations (Hammiche et al. 2013). Poisoning also causes mydriasis, dryness of the mucous membranes, headache, delirium, and coma (Bellakhdar 1997).

The lowest use value is attributed to the species Anethum graveolens L. This is likely because this plant or its therapeutic virtues were less known by the respondents.

Therefore, the recommendation of these plants based essentially on oral transmission represents a real health risk. Although practitioners of traditional medicine have over time discovered the virtues of these plants, they cannot control their phytochemical and pharmacotoxicological properties (Najem et al. 2018b).

\section{Family use values (FUV)}

The families with the highest UV are Rutaceae (2.293), followed by Urticaceae (1.914), Aristolochiaceae (1.241), and Amaranthaceae (0.879) (Table 2). These families are reported only by one species for each and have different use reports:133 for Rutaceae, 111 for Urticaceae, 72 for Aristolochiaceae, and 51 for Amaranthaceae. The families with low FUV are Buxaceae and Poaceae (0.052).

Although some families are the most represented in terms of poisonous medicinal plants in the study area (Najem et al. 2019a), they do not have high FUV, such as Lamiaceae with 13 species, 224 use reports, and FUV = 0.297; Asteraceae with 12 species, 158 use reports, and FUV $=0.227$; and Apiaceae with 9 species, 184 use reports, and FUV $=0.352$. Thus, we can deduce that the ethnobotanical value of the use of families does not depend on their number of taxa, but rather on the importance and use value of those taxa.

\section{Relative frequency of citation (RFC)}

The RFC value ranges from 0 to 1 ; when it nears 0 , it demonstrates that none of the respondents referred to this plant as useful and when it nears 1 , it indicates that this plant was considered useful by almost all respondents (Tardio \& Pardo-de Santayana 2008). Thus, our results show that the RFC of medicinal plants used by the respondents in traditional recipes ranges between 0.81 and 0.017 . Poisonous medicinal plants with high RFC are Anacyclus pyrethrum L. (0.810), Aristolochia paucinervis Pomel (0.552), Urtica urens L. (0.534), Corrigiola telephiifolia Pour. (0.517), and Verbascum sinuatum L. (0.50) (Table 1). These plants were well known by the practitioners of traditional medicine, because, in addition to their therapeutic virtues, they are widespread in the study area.

Table 2. Family use values of poisonous medicinal plants solicited in traditional herbal medicine in the central Middle Atlas region

\begin{tabular}{|l|l|l|l|}
\hline Familles & UvS & Ns & FUV \\
\hline Acanthaceae & 0.224 & 1 & 0.224 \\
\hline Amaranthaceae & 0.879 & 1 & 0.879 \\
\hline Anacardiaceae & 0.914 & 2 & 0.457 \\
\hline Apiaceae & 3.172 & 9 & 0.352 \\
\hline Apocynaceae & 0.293 & 1 & 0.293 \\
\hline Aristolochiaceae & 1.241 & 1 & 1.241 \\
\hline Asteraceae & 2.724 & 12 & 0.227 \\
\hline Berberidaceae & 0.207 & 1 & 0.207 \\
\hline Boraginaceae & 0.328 & 2 & 0.164 \\
\hline Brassicaceae & 0.586 & 4 & 0.147 \\
\hline Buxaceae & 0.052 & 1 & 0.052 \\
\hline Caprifoliaceae & 0.121 & 1 & 0.121 \\
\hline Caryophyllaceae & 0.707 & 2 & 0.353 \\
\hline Cistaceae & 0.155 & 1 & 0.155 \\
\hline Cyperaceae & 0.172 & 1 & 0.172 \\
\hline Ericaceae & 0.086 & 1 & 0.086 \\
\hline Euphorbiaceae & 0.293 & 2 & 0.147 \\
\hline Fabaceae & 0.586 & 3 & 0.195 \\
\hline Lamiaceae & 3.862 & 13 & 0.297 \\
\hline Lauraceae & 0.621 & 1 & 0.621 \\
\hline Liliaceae & 0.621 & 2 & 0.310 \\
\hline Pinaceae & 0.069 & 1 & 0.069 \\
\hline Poaceae & 0.103 & 2 & 0.052 \\
\hline Portulacaceae & 0.241 & 1 & 0.241 \\
\hline Ranunculaceae & 0.207 & 2 & 0.103 \\
\hline Rhamnaceae & 0.224 & 1 & 0.224 \\
\hline Rosaceae & 0.397 & 2 & 0.198 \\
\hline Rubiaceae & 0.276 & 1 & 0.276 \\
\hline Rutaceae & 2.293 & 1 & 2.293 \\
\hline Scrophulariacea & 1.345 & 2 & 0.672 \\
\hline Solanaceae & 1.086 & 3 & 0.362 \\
\hline Taxaceae & 0.172 & 1 & 0.172 \\
\hline Thymeleaceae & 0.241 & 2 & 0.121 \\
\hline Urticaceae & 1.914 & 1 & 1.914 \\
\hline Zygophyllaceae & 0.190 & 1 & 0.190 \\
\hline
\end{tabular}


Moreover, Anacyclus pyrethrum L. is an endemic toxic medicinal plant popular in Morocco distributed precisely in the study area (Najem et al. 2019a).

For the use value, the lowest RFC is recorded by Anethum graveolens L. (0.017), which is likely because this plant was little known by the informants or they did not consider it useful for certain diseases.

\section{Relative importance (RI)}

Regarding the relative importance index, the most important versatile use is attributed to the plant Carum carvi L. (RI = 95) (Table 1), since it has the most pharmacological properties exploited in the most use categories.

\section{Cultural importance index $(\mathrm{Cl})$}

The quantitative study showed that the $\mathrm{Cl}$ value varies between 0.155 and 0.017 (Table 1). The poisonous medicinal plants used in the study area with the highest $\mathrm{Cl}$ values are Carum carvi L. (0.155), Ziziphus lotus (L.) Lam. (0.138), Cedrus atlantica (Manetti.) Carr. (0.121), Angelica archangelica L. (0.103), Asphodelus macrocarpus Parl. (0.103), Agropyrum repens (L.) PB. (0.103), and Daphne gnidium L. (0.103). The plants with the lowest $\mathrm{Cl}$ values are Pistacia lentiscus L., Ammi majus L., Coriandrum sativum L., Anthemis nobilis L., Artemisia arborescens L., Senecio sp., Heliotropium europaeum L., Brassica nigra (L.) W.D.J. Koch, Cistus ladaniferus L., Arbutus unedo L., Euphorbia helioscopia L., Salvia verbenaca L., Paeonia coralline Retz spp. coriacea (Boiss.) Coss., and Peganum harmala L.

\section{Fidelity level (FL)}

The calculation of the fidelity index enables to determine the most used toxic species applied to treat a given disease. A high FL indicates a high usage of the plant species for a particular ailment, whereas a low FL demonstrates a wide range of medicinal uses but with a low frequency for each ailment (Yaseen et al. 2015).

The species with the highest fidelity for the treatment of a wide range of diseases is Ruta montana L., which has the highest $\mathrm{FL}$ for the treatment of respiratory $(\mathrm{FL}=43.10 \%)$, oral $(\mathrm{FL}=43.10 \%)$, and neurological diseases $(F L=18.97 \%)($ Table 3$)$.

Table 3. Fidelity level of toxic medicinal plants solicited in traditional herbal medicine in the central Middle Atlas

\begin{tabular}{|c|c|}
\hline IIIness category & Fidelity level of species (\%) \\
\hline Dermatological disorders & $\begin{array}{l}\text { Aristolochia paucinervis Pomel. (55.17), Ruta montana L. (43.10), Urtica urens L. } \\
\text { (39.66), Solanum sodomaeum L. (34.48), Marrubium vulgare L. (29.31), } \\
\text { Verbascum sinuatum L. (24.14), Nerium oleander L. (17.24), Salvia verbenaca L. } \\
\text { (17.24). }\end{array}$ \\
\hline Respiratory disorders & $\begin{array}{l}\text { Ruta montana L. (43.10), Marrubium vulgare L. (36.21), Urtica urens L. (36.21), } \\
\text { Chenopodium ambrosioides L. (29.31), Corrigiola telephiifolia Pour. (25.86), } \\
\text { Verbascum sinuatum L. (17.24), Ammi visnaga (L.) Lam. (15.52), Digitalis } \\
\text { mauretanica (Emberger\& Maire) Ivaina L. (15.52), Nerium oleander L. (12.07), } \\
\text { Anacyclus pyrethrum DC. (15.52), Teucrium polium L. (15.52). }\end{array}$ \\
\hline Cardiovascular diseases & $\begin{array}{l}\text { Ammi visnaga (L.) Lam. (20.69), Digitalis mauretanica (Emberger \& Maire) Ivaina } \\
\text { L. (13.79), Echinops spinosus L. (12.07), Pistacia lentiscus L. (10.34). }\end{array}$ \\
\hline Urogenital disorders & $\begin{array}{l}\text { Urtica urens L. (39.66), Ruta montana L. (36.21), Ammi visnaga (L.) Lam. (25.86), } \\
\text { Aristolochia paucinervis Pomel. (22.41), Solanum sodomaeum L. (22.41), } \\
\text { Acanthus mollis L. (12.07). }\end{array}$ \\
\hline Osteoarticular disorders & $\begin{array}{l}\text { Urtica urens L. (43.10), Chenopodium ambrosioides L. (41.38), Verbascum } \\
\text { sinuatum L. (29.31), Laurus nobilis L. (22.41), Urginea maritima (L.) Baker. (22.41), } \\
\text { Anacyclus pyrethrum DC. (15.52), Astragalus Iusitanicus Lam. (15.52), Ferula } \\
\text { communis L. (13.79), Ruta montana L. (13.79), Taxus baccata L. (12.07). }\end{array}$ \\
\hline Digestive tract disorders & $\begin{array}{l}\text { Aristolochia paucinervis Pomel. (29.31), Carum carvi L. (29.31), Rubia tinctorum L. } \\
\text { (27.59), Marrubium vulgare L. (27.59), Pistacia lentiscus L. (24.14), Ruta montana } \\
\text { L. (22.41), Ammi visnaga (L.) Lam. (20.69), Laurus nobilis L. (20.69), Corrigiola } \\
\text { telephiifolia Pour. (18.97), Origanum majorana L. (18.97), Ocimum basilicum L. } \\
\text { (17.24), Chenopodium ambrosioides L. (17.24), Teucrium polium L. (15.52), } \\
\text { Pimpinella anisum L. (15.52), Cistus ladaniferus L. (15.52). }\end{array}$ \\
\hline Neurological disorders & Ruta montana L. (18.97), Cyperus longus L. (8.62), Pistacia atlantica Dsf. (3.45). \\
\hline Ophthalmic disorders & $\begin{array}{l}\text { Verbascum sinuatum L. (50.00), Ocimum basilicum L. (6.90), Berberis vulgaris L. } \\
\text { (5.17), Ferula communis L. (3.45), Foeniculum vulgare P. Mill. (3.45). }\end{array}$ \\
\hline Oral disorders & $\begin{array}{l}\text { Ruta montana L. (43.10), Ammi visnaga (L.) Lam. (36.21), Laurus nobilis L. } \\
\text { (20.69), Marrubium vulgare L. (20.69), (18.97), Pistacia atlantica Dsf. (15.52), } \\
\text { Echinops spinosus L. (15.52), Anacyclus pyrethrum DC. (12.07), Atractylis } \\
\text { gummifera L. (12.07). }\end{array}$ \\
\hline
\end{tabular}


In the Mediterranean region, Ruta montana $\mathrm{L}$. is a panacea and its uses are similar (Boulos 1983, Pollio et al. 2008). Aristolochia paucinervis Pomel. also has high fidelity for the treatment of dermatological diseases $(\mathrm{FL}=55.17 \%)$ and digestive diseases ( $\mathrm{FL}$ $=29.31 \%$ ). Other ethnobotanical studies have shown that Aristolochia paucinervis Pomel. is used to treat aortic palpitations, constipation and intestinal disorders, colic, and gaseous gangrene; it is also used to treat skin diseases and infections such as ringworm, dermatitis, impetigo, and fungal infections. Many traditional healers prescribe the ingestion of a mixture of small amounts of root powder with honey or salted butter to treat abdominal pain, particularly epigastric distress (Bellakhdar et al. 1991, Bellakhdar 1997, Sijelmassi 2011, Ouarghidi et al. 2013). The study informants indicated that Urtica urens $\mathrm{L}$. is used most often to treat osteoarticular (FL $=43.10 \%)$ and urogenital $(\mathrm{FL}=39.66 \%)$ diseases, in line with earlier reports (Nassiri et al. 2016).

However, other plants show a restricted fidelity for the treatment of a single disease category; this is the case for Ammi visnaga (L.) Lam. (FL $=20.69 \%)$ and Verbascum sinuatum $\mathrm{L}$. ( $\mathrm{FL}=50.00 \%$ ), which are used for treating cardiovascular and ophthalmic diseases, respectively.

According to the respondents, parts of the plants used in medication (column 4 in Table 1) can cause poisoning (Najem et al. 2019a, Najem et al. 2019b). This could be due to excessive use (duration and dose) or preparation and administration errors (Najem et al. 2018a).

\section{Informant consensus factor (ICF)}

Table 4 shows that the ICF varies between 0.035 and 0.743 . Ophthalmic disorders have the highest ICF (0.743), with 36 use reports for 10 species, followed by neurological disorders ( 0.733$)$ and cardiovascular diseases (0.613). Plants with a high ICF value are thought to be effective for treating particular diseases and should be investigated for the discovery of new active molecules. Also, the high ICF value reflects an agreement among the respondents on the recommendation of certain toxic plants to treat a given disease.

The lowest agreement between the informants (ICF $=0.035$ ) is observed for the poisonous medicinal plants used to treat digestive tract diseases. This can be explained by a lack of communication between the traditional medicine practitioners, the wealth of the active plants available to treat these kinds of diseases (56 species used), or the similarities in these plants' active compounds, resulting in similar effects.

Table 4. Informant consensus factor of poisonous medicinal plants solicited in traditional herbal medicine in the central Middle Atlas region

\begin{tabular}{|l|l|l|l|}
\hline Illness category & $\mathbf{N}_{\mathbf{t}}$ & $\mathbf{N}_{\mathbf{u r}}$ & $\mathbf{F C I}$ \\
\hline Dermatological disorders & 38 & 58 & 0.351 \\
\hline Respiratory disorders & 25 & 55 & 0.556 \\
\hline Cardiovascular diseases & 13 & 32 & 0.613 \\
\hline Urogenital disorders & 36 & 55 & 0.352 \\
\hline Osteoarticular disorders & 30 & 56 & 0.473 \\
\hline Digestive tract disorders & 56 & 58 & 0.035 \\
\hline Neurological disorders & 5 & 16 & 0.733 \\
\hline Ophthalmic disorders & 10 & 36 & 0.743 \\
\hline Oral disorders & 21 & 51 & 0.600 \\
\hline
\end{tabular}

\section{Correlation analysis}

The UV and the RFC appear to be significantly correlated with a high determination coefficient $\left(R^{2}=\right.$ 0.6 ; Fig. 2). There is no correlation between the RFC and $\mathrm{RI}\left(\mathrm{R}^{2}=0.00189\right)$ or between the RFC and $\mathrm{Cl}$ $\left(R^{2}=0.00204\right)$. Similarly, there is no correlation between the UV and the RI $\left(R^{2}=0.000997\right)$ and between the UV and the $\mathrm{Cl}\left(\mathrm{R}^{2}=0.000928\right)$ (Fig. 3). In contrast, a highly significant correlation is observed between the $\mathrm{RI}$ and the $\mathrm{Cl}\left(\mathrm{R}^{2}=0.9999\right)$, which implies that any species studied has cultural importance and significant versatile use.

\section{Conclusions}

The ethnobotanical results of this study affirm the conservation of traditional herbal heritage by the practitioners of traditional medicine in the central Middle Atlas region; unfortunately, many of the plants that were used as phyto-remedies to treat various diseases were reported toxic and their frequent use was confirmed by the calculation of quantitative indices such as the UV, RFC, FUV, FL, $\mathrm{IR}, \mathrm{Cl}$, and ICF.

The recourse of these practitioners to poisonous medicinal plants for the preparation of their recipes reveals a dangerous health risk, especially with irrational use. The present results can be used to complete the Moroccan medicinal flora database. A draft of more thorough studies, especially chemical and pharmacotoxicological research, will be submitted to more precisely understand the use of such poisonous plants by traditional medicine practitioners for traditional herbal medication. 

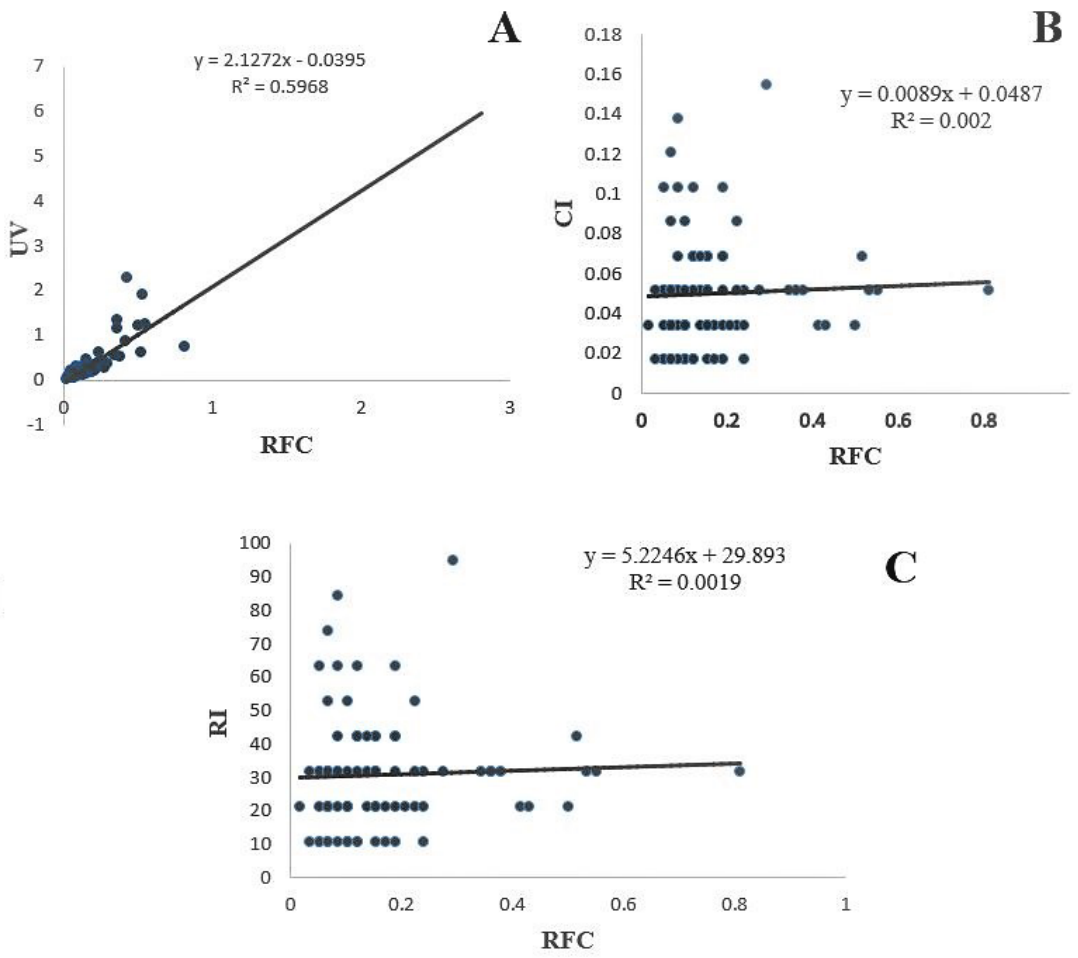

C

Fig. 2. Correlation between the relative frequency of citation (RFC) and the different quantitative indices:(A) use value (UV), (B) cultural importance index (Cl), and (C) relative importance (RI).
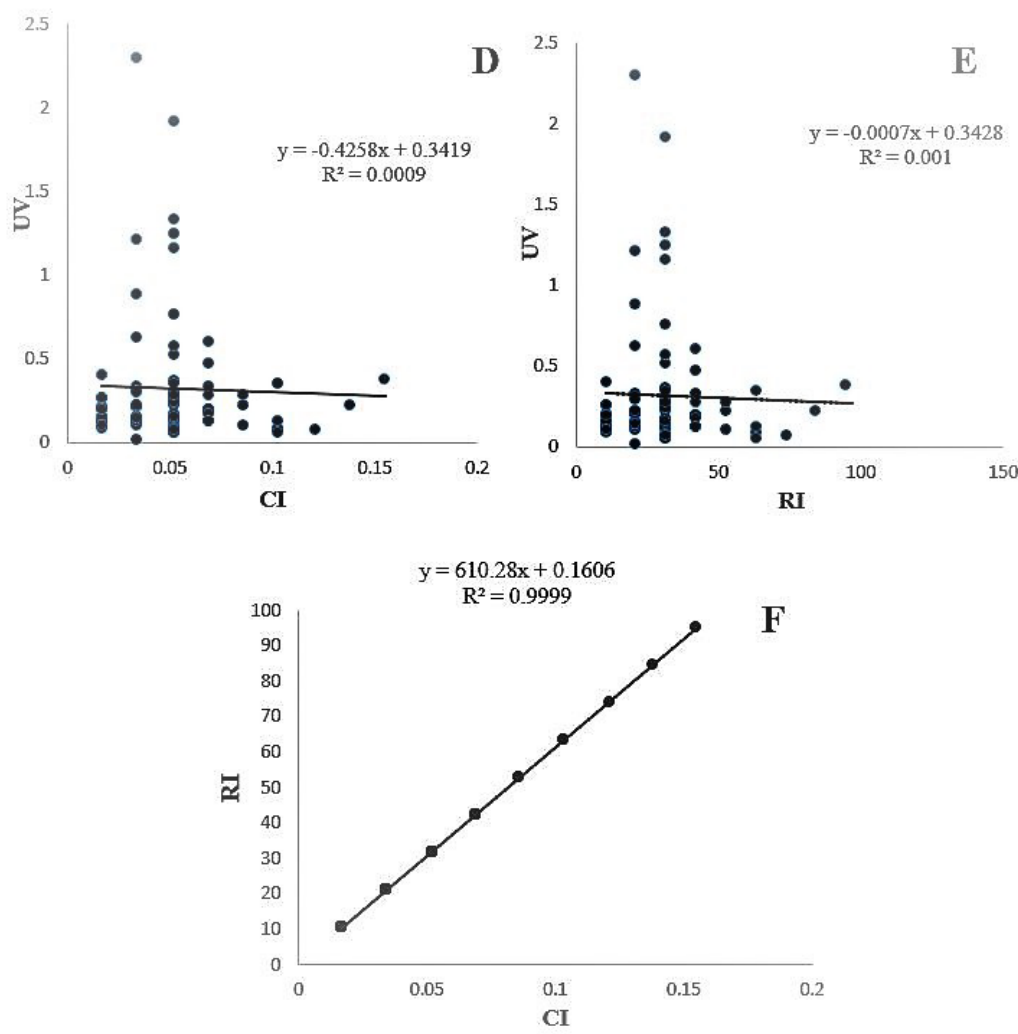

Fig. 3. Correlation among the different quantitative indices:(D) between the use value and the cultural importance, $(E)$ between the use value and the relative importance, and $(F)$ between the relative importance and the cultural importance. 


\section{Declarations}

List of abbreviations:

Cultural Importance Index:CI

Family Use Values:FUV

Fidelity Level:FL

Informant Consensus Factor:ICF

Relative Frequency of Citation:RFC

Relative Importance:RI

Use Value:UV

Ethics approval and consent to participate: All participants gave their prior consent knowing the reason for the study.

Consent for publication: Not applicable.

Availability of data and materials: The data was not deposited in public repositories.

Competing interests: The authors do not have any competing interests.

Funding: This research did not receive funding.

Authors' contributions:

MN wrote the manuscript, conducted the ethnobotany survey, and calculated the; $\mathrm{LN}$ and $\mathrm{Jl}$ contribvuted to the manuscript.

\section{Acknowledgements}

At the end of this work, we would like to thank the traditional medicine practitioners in the study area for the time, availability and all the information provided.

\section{Literature Cited}

Bellakhdar J. 1997. La pharmacopée marocaine traditionnelle, médecine arabe ancienne et savoirs populaires. Editions Le Fennec, Ibis Press, Maroc, Casablanca.

Bellakhdar J, Claisse R, Fleurentin J, Younos C. 1991. Repertory of standard herbal drugs in the Moroccan pharmacopoeia. Journal of Ethnopharmaciology 35:123-143.

Benabid A. 2002. Le Rif Et Le Moyen-Atlas (Maroc):Biodiversite, Menaces, Preservation. African Mountains High Summit Conference. Nairobi, Kenya.

Benbrahim KF, Ismaili M, Benbrahim SF, Tribak A. 2004. Problèmes de dégradation de l'environnement par la désertification et la déforestation:impact du phénomène au Maroc. Science et changements planétaires/Sécheresse 15(4):307-320.
Bennett BC, Prance GT. 2000. Introduced plants in the indigenous pharmacopoeia of Northern South America. Economic Botany 54(1):90-102.

Benzakour G, Benkirane N, Amrani M, Oudghiri M. 2011. Immunostimulatory potential of Aristolochia longa $L$. induced toxicity on liver, intestine and kidney in mice. Journal of Toxicology and Environmental Health Sciences 3(8):214-222.

Bnouham M, Merhfour FZ, Elachoui M, Legssyer A, Mekhfi H, Lamnaouer D, Ziyyat A. 2006. Toxic effects of some medicinal plants used in Moroccan traditional medicine. Moroccan Journal of Biology 2(3):21-30.

Boujrouf S. 2004. Tourisme de montagne au Maroc:enjeux de la durabilté. Le tourisme durable, réalités et perspectives marocaines et internationales 273-284.

Boulos L. 1983. Medicinal plants of North Africa. Publications Inc, USA, Michigan, Algonac.

Cadena-González AL, Sørensen M, Theilade I. 2013. Use and valuation of native and introduced medicinal plant species in Campo Hermoso and Zetaquira, Boyacá, Colombia. Journal of Ethnobiology and Ethnomedicine 9:1-34.

Cham BE, Meares HM. 1987. Glycoalcaloides from Solanum sodomaeum are effective in the treatement of skin cancers in man. Cancer Letters 36(2):111118.

De Albuquerque UP, Hanazaki N. 2009. Five problems in current ethnobotanical research-and some suggestions for strengthening them. Human Ecology 37(5):653-661.

Dossou ME, Houessou GL, Lougbégnon OT, Tenté $\mathrm{AH}$, Codjia JT. 2012. Etude ethnobotanique des ressources forestières ligneuses de la forêt marécageuse d'Agonvè et terroirs connexes au Bénin. Tropicultura 30(1):41-48.

El Jihad M.D. (2016). Changement climatique et développement rural dans les montagnes du MoyenAtlas et leurs bordures (Maroc). Journal of Alpine Research | Revue de géographie alpine 104(4):1-18.

El Rhaffari L, Zaid A. 2002. Pratique de la phytothérapie dans le sud-est du Maroc (Tafilalet) :un savoir empirique pour une pharmacopée rénovée. Des sources du savoir aux médicaments du futur :actes du $4 \mathrm{e}$ congrès européen d'ethnopharmacologie. Paris (FRA), Metz, IRD, SFE, 293-318.

Fennane M, Ibn Tattou M. 2012. Statistiques et commentaires sur l'inventaire actuel de la flore vasculaire du Maroc. Bulletin de l'Institut Scientifique, Rabat, section Sciences de la Vie 34(1):1-9. 
Fennane M, Ibn Tattou M, El Oulaidi J. 2014. Flore pratique du Maroc. Vol 3,Travaux Institut Scientifique. Sér. Botanique $N^{\circ} 40$, Rabat, Maroc.

Fennane M, Ibn Tattou M, Mathez J, Ouyahya A, El Oulaidi J. 1999. Flore pratique du Maroc. vol 1, Travaux Institut Scientifique, Sér. Botanique $N^{\circ} 36$, Rabat, Maroc.

Fennane M, Ibn Tattou M, Ouyahya A, El Oulaidi J. 2007. Flore pratique du Maroc. Vol 2, Travaux Institut Scientifique, Sér. Botanique $\mathrm{N}^{\circ} 38$, Rabat, Maroc.

Fleurentin J. 1993. Ethnopharmacologie et aliments:Introduction au sujet et réflexions sur l'efficacité biologique. Actes du $2^{\mathrm{e}}$ Colloque Européen d'Ethnopharmacologie et de la $11^{\mathrm{e}}$ Conférence Internationale d'Ethnomédecine, Médlcaments et aliments:L'approche ethnopharmacologique. Heidelberg. 1-7.

Hammiche V, Merad R, Azzouz M. 2013. Plantes toxiques à usage médicinal du pourtour méditerranéen. Springer-Verlag, France, Paris.

Heinrich M, Ankli A, Frei B, Weimann C, Sticher O. 1998. Medicinal plants in Mexico:Healers' consensus and cultural importance. Social Science \& Medicine 47(11):1859-1871.

Houéhanou DT, Assogbadjo AE, Chadare FJ, Zanvo S, Sinsin B. 2016. Approches méthodologiques synthétisées des études d'ethnobotanique quantitative en milieu tropical. Annales des Sciences Agronomiques 20 - spécial Projet Undesert-UE:187205.

Jamaleddine M, El Oualidi J, Taleb M, ThéveninT, El Alaoui-Faris FE. 2017. Inventory and Conservation Status of Aromatic and Medicinal Plants in Morocco. Phytothérapie 15(3):114-122.

Mahmoudi A, Bertrand H. 2007. Identification géochimique de la province magmatique de l'Atlantique central en domaine plissé:exemple du Moyen Atlas marocain. Comptes Rendus Geoscience 339(8):545-552.

Martin J. 1981. Le Moyen-Atlas Central:étude géomorphologique. Notes et mémoires du Service Géologique du Maroc, Editions du Service Géologique de Maroc, Rabat.

Masri W, Belwaer I, Khlifi F, Nouioui A, Ben salah D, Amira D, Hedhili A. 2015. A propos d'un cas d'intoxication aigüe par Ruta montana. Phytotherapie 13:36-38.

Miranda TM, De Mello Amorozo MC, Govone JS, Miranda DM. 2007. The influence of visual stimuli in ethnobotanical data collection using the listing task method. Field Methods 19(1):76-86.
Musa MS, Abdelrasool FE, Elsheikh EA, Ahmed L, Mahmoud AL, Yagi SM. 2011. Ethnobotanical study of medicinal plants in the Blue Nile State, Southeastern Sudan. Journal of Medicinal Plants Research. 5(17):4287-4297.

Nacoulma E, Sakande J, Kafando E, Kpowbié ED, Guissou IP. 2006. Profil hématologique et biochimique des drépanocytaires SS et SC en phase stationnaire au Centre Hospitalier National Yalgado Ouedraogo de Ouagadougou. Mali Medical 21(1):811.

Najem M, Belaidi $R$, Harouak $H$, Bouiamrine $E H$, Ibijbijen J, Nassiri L. 2018 a. Occurrence de plantes toxiques en phytothérapie traditionnelle dans la région du Moyen Atlas central Maroc. Journal of Animal \& Plant Sciences 35(2):5651-5673.

Najem M, Belaidi R, Slimani I, Bouiamrine El H, Ibijbijen J, Nassiri L. 2018 b. Pharmacopée traditionnelle de la région de Zerhoun - Maroc :connaissances ancestrales et risques de toxicité. Int. J. Biol. Chem. Sci. 12(6):2797-2807.

Najem M, Daoudi A, Bouiamrine EH, Ibijbijen J, Nassiri L. 2019 a. Biodiversity of poisonous medicinal plants solicited in the traditional phytotherapy of the central Middle Atlas -Morocco. Ethnobotany Research \& Applications 18(19):1-23.

Najem M, Nassiri L, Daoudi A. 2019 b. Plantes médicinales au Moyen Atlas central entre thérapie et toxicité. Editions universitaires européennes, Riga, Latvia, European Union.

Nassiri L, Zarkani S, Daoudi A, Bammou M, Bouiamrine EH, Ibijbijen J. 2016. Contribution to the establishment of ethno botanical catalog of Aguelmous (Khenifra, Morocco). International Journal of Innovation and Applied Studies 17(2):373387.

Nawash O, Shudiefat M, Al-Tabini R, Al-Khalidi K. 2013. Ethnobotanical study of medicinal plants commonly used by local Bedouins in the Badia region of Jordan. Journal of Ethnopharmacology 148:921-925.

Ouarghidi A, Martin GJ, Powell B, Esser G, Abbad A. 2013. Botanical identification of medicinal roots collected and traded in Morocco and comparison to the existing literature. Journal of Ethnobiology and Ethnomedicine 9(59):1-13.

Pardo-de-Santayana M, Tardío J, Blanco E, Carvalho AM, Lastra JJ, San Miguel E, Morales R. 2007. Traditional knowledge on wild edible plants in the northwest of the Iberian Peninsula (Spain and Portugal):a comparative study. Journal of Ethnobiology and Ethnomedicine 3(27):1-11.

Pollio A, De Natale A, Appetiti E, Aliotta G, Touwaide A. 2008. Continuity and change in the Mediterranean 
medical tradition:Ruta spp. (Rutaceae) in Hippocratic medicine and present practices. Ethopharmacol 116:469-482.

Rankou H, Ouhammou A, Taleb M, Martin G. 2015. Aristolochia paucinervis. The IUCN Red List of Threatened Species. doi:10.2305/IUCN.UK.20154.RLTS.T53785726A53798727.en.

Seak CJ, Lin CC. 2007. Ruta graveolens intoxication. Clinical Toxicology 45 (2):173-175.

Sijelmassi A. 2011. Les plantes médicinals du Maroc. Editions Le Fennec, Maroc, Casablanca.

Singh AP, Kumar M, Nagar B, Pala NA, Bussmann RW. 2019. Ethnomedicinal use of plant resources in Kirtinagar Block of Tehri Garhwal in Western Himalaya. Ethnobotany Research \& Applications 18(14):1-11.

Tardio J, Pardo-de Santayana M. 2008. Cultural importance indices:a comparativeanalysis based on the useful wild plants of southern Cantabria (Northern Spain). Economic Botany 62(1):24-39.

Vitalini S, Iriti M, Puricelli C, Ciuchi D, Segale A, Fico G. 2013. Traditional knowledge on medicinal and food plants used in Val San Giacomo (Sondrio, Italy)-an alpine ethnobotanical study. Journal of Ethnopharmacology 145:517-529.

Yaseen G, Ahmad M, Sultana S, Suleiman Alharrasi A, Hussain J, Zafar M, Shafiq-Ur-Rehman. 2015. "Ethnobotany of Medicinal Plants in the Thar Desert (Sindh) of Pakistan. Journal of Ethnopharmacology 163:43-59.

Zougagh S, Belghiti A, Rochd T, Zerdani I, Mouslim J. 2019. Medicinal and Aromatic Plants Used in Traditional Treatment of the Oral Pathology:The Ethnobotanical Survey in the Economic Capital Casablanca, Morocco (North Africa). Natural products and bioprospecting 9(1):35-48. 